\title{
Governance and the making and breaking of social-ecological traps
}

\author{
Dana M. Baker ${ }^{1}$ Grant Murray $^{1}$ and Andrew Kvei Agvare ${ }^{2}$
}

\begin{abstract}
Many countries in sub-Saharan Africa have areas of significant ecological importance that overlap with pressing development needs and high levels of natural resource dependence. This makes the design of effective natural resource governance and management systems both challenging and critical. In Ghana, this challenge is made more complex by the necessity of connecting formal, state-led systems of governance with Ghana's informal governance systems through which customary authorities exert considerable control over land and resources. We present findings from two multimethod research projects in two regions of Ghana that have significant issues related to resource exploitation and that have experienced extensive management interventions. The goals of the research were to characterize the social-ecological traps from a local perspective, to describe how governance and management structures interact with and relate to those traps, and to discuss the strategies used and challenges encountered when community-based natural resource management initiatives seek to reverse persistent social-ecological traps. In both case studies, participants described persistent cycles of resource dependence, overexploitation, and unsustainable land-use practices, which are exacerbated by illegal logging, intensive agricultural development, and population growth. Findings highlight how natural resource management is constrained by a lack of capacity to implement and enforce state policies, ongoing tension between customary and state institutions, and ambiguity regarding management responsibility and resource tenure. Interventions included targeted governance reform that centred on improving linkages between customary and state institutions, new and nonlocal actors, and complementary investments in capacity building and training. We conclude with a discussion of implications for the design of effective natural resource governance regimes in Ghana and beyond.
\end{abstract}

Key Words: community-based management; conservation; decentralization; Ghana; governance; protected areas

\section{INTRODUCTION}

Community-based natural resource management (CBNRM) arrangements are frequently advocated as solutions to the failures of top-down, centralized approaches to achieve linked conservation and development objectives (Hulme and Murphree 1999, Leach et al. 1999, Levine 2016). The establishment of CBNRM arrangements involves a shift in authority to manage resources and includes efforts to effectively link local administrative units, social groups, and institutions into the structures and processes of governance (Lemos and Agrawal 2006). The need to develop effective governance arrangements for managing natural resources is particularly acute in Sub-Saharan Africa, where many individuals in rural communities are trapped in cycles of environmental degradation and poverty (Lawson et al. 2012, Egyir et al. 2015).

Social-ecological traps are an emerging concept used to characterize interactions between people and the surrounding environment, as well as the processes that drive systems toward unsustainable and undesirable states (Cinner 2011, Boonstra and De Boer 2014, Boonstra et al. 2016). Traps occur when there is an ongoing, negative mismatch between the current ecological condition and people's interaction with their surrounding resources (Boonstra and De Boer 2014, Boonstra et al. 2016). Although formal and informal governance institutions can reverse the processes that lead to entrapment, weak or inappropriate governance institutions can also create or exacerbate traps, leading to increasing rates of resource degradation and poverty (Cinner et al. 2016). Thus, a deeper understanding of the pathways into and out of social-ecological traps is critical to inform the production, application, and adaptation of natural resource governance arrangements.
The implementation of new governance arrangements, such as CBNRM, has the potential to slow down and reverse the processes that create and maintain social-ecological traps. However, as several authors have noted, the rhetoric of decentralization and devolution as part of CBNRM is not always matched by the scope of institutional reforms necessary for effective implementation (Leach et al. 1999, Ribot 2002, Batterbury and Fernando 2006, Roe et al. 2009, Clement 2010, Miller et al. 2013, Mcgregor et al. 2014). This draws attention not only to decentralization and CBNRM policies themselves, but also to how they play out on the ground. Likewise, the linkages and interplay among governance structures at different scales are recognized as an important mediator of CBNRM performance, highlighting the need to understand how and why linkages, or the absence thereof, affect outcomes (Agrawal and Gibson 1999, Ostrom et al. 1999, Adger et al. 2005, Naughton-Treves et al. 2005, Young 2006, Berkes 2007a, $b$ ). In Ghana, for example, social-ecological traps are exacerbated by the persistence of a pluralistic, decentralized land-management system that features an uneasy interplay between customary tenure regimes and formal government institutions. Although Ghana's forest and savannah ecosystems support a rich biodiversity vital to local and national economies (GG-MLNR 2016), government policies surrounding land and tree tenure since the imposition of colonial rule and the modern state have interacted with other changes to concentrate economic power in the state, reduce individual incentives to conserve natural resources, and weaken customary management institutions (Kasanga and Kotey 2001, Boni 2006, Kuusaana and Gerber 2015). This has fueled uncertainty around access to land and resources, as well as responsibility for policy enforcement and management (Kasanga and Kotey 2001, Aryeetey and Udry 2010).

${ }^{1}$ Duke University Marine Lab, Nicholas School of Environment, Duke University, Beaufort, North Carolina, ${ }^{2}$ Ghana Wildlife Division of the Forestry Commission, Accra, Ghana 
To address issues of resource conservation on community lands and in tandem with national policies of decentralization, Ghana reoriented its approach to CBNRM by developing and implementing the community resource management area (CREMAs) program (Baruah et al. 2016). The CREMA concept was officially conceived in Ghana's 1994 Forest and Wildlife Policy, though it took over a decade for the concept to come into action (Asare et al. 2013). Community resource management areas are geographically defined areas created when participating communities agree to manage all or part of their land under a framework guided by a mutually agreed upon constitution. By partially transferring management rights back to community groups, the program endeavors to enhance livelihoods, promote sustainable environmental governance and democratic participation, and to reverse trends of environmental degradation (GG-WDG 2004, Baruah et al. 2016). According to unpublished data from the Wildlife Division, there are currently 32 CREMAs at different stages of development, 24 of which have obtained official certificates of devolution (Agyare 2017, personal observation).

We present results from two independent research projects sharing a case study approach in which each case features significant issues related to resource exploitation and involves noteworthy management interventions, including the use of the CREMA mechanism. Specific objectives include: (1) characterizing socialecological traps from a local perspective, (2) describing how governance and management structures interact with and relate to those traps, and (3) discussing the strategies used and challenges encountered when CBNRM initiatives seek to reverse persistent social-ecological traps.

\section{METHODS}

\section{Background and description of study sites}

The first case study is located in the southern portion of the Akwapim-Togo mountain range in the Volta Region of Ghana, within the larger Guinean forest ecosystem (Fig. 1). The Akwapim-Togo Mountains are a narrow band of ridges and hills beginning west of Accra that extend northeast into Togo and Benin. The landscape is a mosaic of habitats and land uses in which subsistence agriculture, hunting, and trading are the main economic activities. The major ethnic groups are Ewe, Akan, and Guan. Land used for settlement and farming is largely held in tenancy arrangements and is not bought or sold (Kludze 2000). The Akwapim-Togo Mountains were identified as a target landscape for the Community Development and Knowledge Management (COMDEKs) for the Satoyama Initiative Project, implemented in partnership with the United Nations Development Program's Small Grant Program (UNDP SGP). Beginning in 2012, this internationally funded project was designed to support a range of sustainable livelihood activities aimed at rebuilding degraded ecosystem services and boosting rural community development.

The second case study focuses on Zukpiri CREMA, a 420-square kilometer management area located along a section of Ghana's border with Burkina Faso (Fig. 1). It lies in the Guinea savanna woodland ecosystem, in the Upper West Region of the country, and is situated just east of the Black Volta River. Land is communally owned, although there are several plots managed directly by families and clans. The establishment of Zukpiri
CREMA was initiated by the Zintang Healers Association, a local traditional healers' association. The CREMA's primary objective is to conserve and improve traditional medicine sources. Zukpiri received its official certificate of devolution in 2011 and was established with technical, logistical, and governance support from the Global Environment Facility (GEF), the UNDP SGP, and the Nadowli District Assembly (Agyare 2013). There are 16 constituent communities participating in the Zukpiri CREMA, predominantly composed of subsistence farmers, who also use the area to rear livestock, hunt, and gather wild fruits and other nontimber forest products (NTFP; Zintang Healers Association 2009).

\section{Data collection}

Akwapim-Togo mountain range

Data were primarily collected from structured community workshops and semistructured key informant interviews, complemented with site visits and ethnographic observation. Key informant interviews were conducted with officials from Ghana's Forestry Commission, fourteen local NGOs, and two international funding agencies. Interviews were conducted in English and focused on how NGOs identified target communities, how project goals were developed, and methods of project implementation. Interviews also included questions about the history of the particular organization and perceived limitations to project implementation. Of the 14 interviews with local NGOs, 10 included site visits that included meetings and transect walks with project participants, typically lasting 4 to 5 hours each. In addition, 12 community workshops were implemented from January to April 2016 and included a total of 329 participants of the COMDEKs program. Each workshop ranged from three to four hours in length.

Community workshops used a strengths, weaknesses, opportunities, and threats (SWOT) framework with a priorityranking scheme (Masozera et al. 2006). Workshops were open to all COMDEK program participants and were facilitated in either Ewe or Guan, depending on the primary language spoken within the community. The purpose of the SWOT analysis was described to participants at the beginning of each workshop. The SWOT factors were defined as attributes that affect individual, community, and environmental well-being, and participants chose to complete the SWOT analysis individually, in pairs, or in small groups. Participants were first asked to list all factors they could think of, using an open-ended approach. After listing all SWOT factors, participants were next asked to rank their top 10 factors in each category, in order of perceived importance, where 1 equaled the most important and 10 equaled the least important. When conducted in smaller groups, consensus was reached within the group for a final group-priority ranking. It is important to note that many SWOT factors emerged in multiple categories. For example, deforestation from chainsaw operators emerged as a threat, whereas deforestation from firewood collection emerged as a weakness. Finally, at the end of each workshop, each ranked SWOT list was presented to the larger group to frame and facilitate a full workshop discussion. After the completion of each workshop, individual and subgroup rankings from each community were averaged to create a final SWOT priority ranking for each community and for the region as a whole. 
Fig. 1. Study area map.

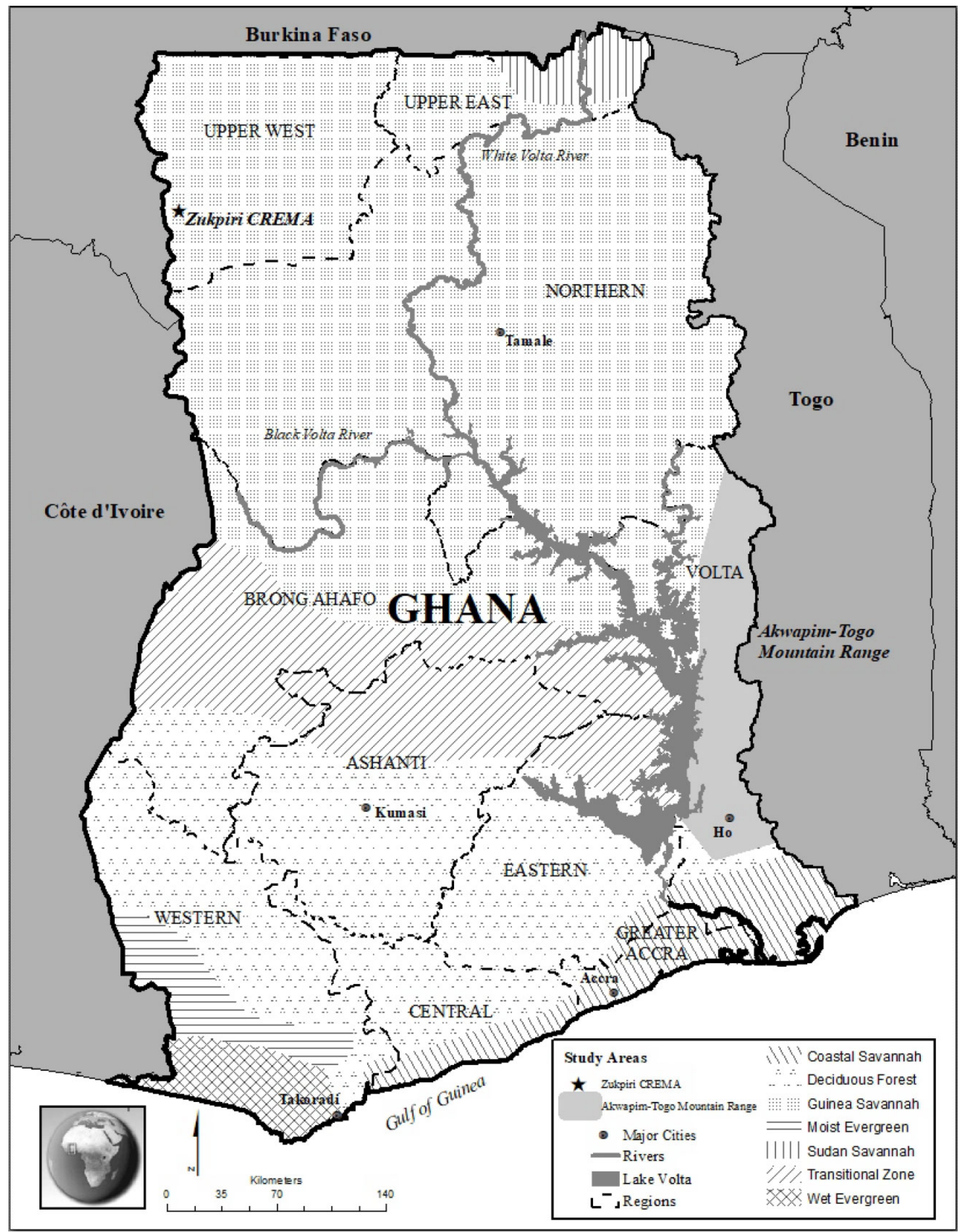

Zukpiri community resource management area (CREMA)

A mixed-methods approach was used, which included document analysis, interviews, focus groups, and household surveys. At the local level, interviews were conducted with $13 \mathrm{key}$ informants including chiefs, opinion leaders, and CREMA executives. In addition, five focus groups were conducted with different occupational groups, including nontimber forest product (NTFP) gatherers, fishers and fish sellers, and enterprise development 
Table 1. Results from the top 5 strengths, weaknesses, opportunities, and threats (SWOT) factors averaged and ranked in order of perceived importance, where 1 is the most important and 5 is the least important, by 12 community groups living in the AkwapimTogo Range, Volta Region, Ghana.

\begin{tabular}{|c|c|c|c|c|}
\hline & Strengths & Weaknesses & Opportunities & Threats \\
\hline 1 (most important) & $\begin{array}{l}\text { good health, physical } \\
\text { strength }\end{array}$ & $\begin{array}{l}\text { limited access to } \\
\text { and limited ability to access } \\
\text { health care facilities }\end{array}$ & $\begin{array}{l}\text { increase number of } \\
\text { technical workshops, } \\
\text { financial trainings at village } \\
\text { level }\end{array}$ & bushfires \\
\hline 2 & $\begin{array}{l}\text { strong sense of community } \\
\text { unity }\end{array}$ & $\begin{array}{l}\text { deforestation from } \\
\text { subsistent activities, } \\
\text { charcoal burning }\end{array}$ & $\begin{array}{l}\text { increase access to financial } \\
\text { capital, loans, and } \\
\text { microloans }\end{array}$ & drought \\
\hline 3 & $\begin{array}{l}\text { strong technical skills/ } \\
\text { farming knowledge }\end{array}$ & $\begin{array}{l}\text { inadequate funds } \\
\text { and capital }\end{array}$ & $\begin{array}{l}\text { better utilization of water } \\
\text { resources, restoration of } \\
\text { water sources }\end{array}$ & illegal chainsaw operators \\
\hline 4 & $\begin{array}{l}\text { possession of strong work } \\
\text { ethic }\end{array}$ & $\begin{array}{l}\text { lack of organizational skills, } \\
\text { institutional capacity }\end{array}$ & $\begin{array}{l}\text { improvement of land and } \\
\text { soil fertility }\end{array}$ & changing climatic patterns \\
\hline 5 (least important) & $\begin{array}{l}\text { time, punctuality, } \\
\text { willingness to perform } \\
\text { communal labor }\end{array}$ & land conflict & $\begin{array}{l}\text { increase access to health } \\
\text { care }\end{array}$ & $\begin{array}{l}\text { soil erosion and declining soil } \\
\text { fertility }\end{array}$ \\
\hline
\end{tabular}

groups. Interview and focus group questions were related to social-ecological issues in the area, the priorities of the communities when developing the CREMA, and the processes of community participation in natural resource governance and management.

The information gathered from the interviews, focus groups, and document analysis was then used to develop a household survey instrument. The survey asked respondents to select the most important outcomes they wanted to see from the establishment of the CREMA. Outcomes were selected from a list of 29 possible CREMA outcomes and included both environmental and socioeconomic aspects. The survey was administered to 247 individuals, including both male and female household heads in 7 (of 16) randomly selected CREMA constituent communities. The survey was administered over a five-month period, from April to August 2012. Finally, eight individuals were interviewed in July 2012 to obtain a more nuanced understanding of the emerging issues identified in the household survey.

\section{RESULTS}

\section{Akwapim-Togo Mountain Range}

Across the Akwapim-Togo Mountain Range, individuals were acutely aware of their changing environment and felt that they lacked the technical, financial, and institutional resources necessary to adapt to shifting climates and degrading ecosystems. Table 1 summarizes the results from the 12 SWOT workshops, listing the top 5 ranked factors in each SWOT category, across all participating communities. The most important factor is listed in the first row and the least important is listed last. Bushfire as a technique for land management, hunting, or farming was widely perceived to be the greatest threat to individual and collective livelihoods across all participating communities. Fire was described as causing severe economic loss when out of control and as a factor that contributes to land degradation when overused. On the other hand, fire as a tool in agriculture was described as widely utilized and the cheapest and least laborintensive method to farm and stake claim to new agricultural land. As one workshop participant stated: "I am a farmer therefore I burn. I burn because I am a farmer.” Respondents described feeling that it was beyond their authority to stop others from setting fires because fire remains an integral and necessary part of rural life. Moreover, participants described feeling that they do not have the capacity or material resources to enforce state fire policy.

Deforestation, specifically from illegal chainsaw operators, was also identified as a top threat in 11 out of the 12 participating communities. Chainsaw operators targeting rosewood (Pterocarpus erinaceus) and other valuable timber species were perceived to work with little oversight. Community members living near a state forest reserve stated that when they report illegal loggers to the appropriate local office nothing happens. In turn, local forestry and wildlife officials stated that they do not have the resources to respond to or to control illegal chainsaw operators, many of whom are armed. Community members expressed that because they cannot legally access, and thus benefit from, the trees themselves, they saw little incentive to enforce state law or to use personal resources to implement forest conservation programs.

Although workshop participants and interviewees recognized the opportunity that reforestation, afforestation, and soil conservation techniques present, they also expressed a resistance to planting trees, labor-intensive soil conservation programs, and other long-term investments in the land because of the uncertainty surrounding future access. This uncertainty was attributed to increasing pressures on the landscape from migratory pastoralists, population growth, industrial agriculture, and drought. For example, one community explained that a large company leased their customary farmland along the River Volta in the late 1980s, which resulted in the relocation of their farms to an area that was perceived to be not as fertile. Significant confusion remained about the stipulations of this lease, who the current legal owners of the land are, and if they could return to farm along the River Volta. Participants stated that this situation was worsened by an inability of either customary or state management systems to adequately address changing issues surrounding the management of natural resources. 
To help mediate landscape and community-level challenges, participants desired an increase in knowledge about agricultural and land management systems. Participants also wanted increased access to technical training and continuing education programs, yet lacked opportunities to deepen their understanding of sustainable agriculture, land management, and bookkeeping techniques. In addition, 10 out of 12 community groups stated that they were unable, unwilling, or did not know how to access the agriculture extension agents (AEAs) that could, in theory, provide this training (AEAs are state government employees that work in rural areas to provide technical advice and links to external markets). The inability to access AEAs was perceived to be a contributing factor to the persistence of unsustainable land management practices, as well as noncompliance with environmental policy.

In response to these types of on-going threats across the landscape, in 2012 the Akwapim-Togo Mountains were identified as a target area for a multiyear, internationally funded project that gave direct financing to a number of community-level organizations. Funding was used to support a suite of ecosystembased management activities, which included sustainable agriculture, reforestation, environmental awareness, and development activities. The project also supported a new collaboration, called the Weto Platform, to better coordinate natural resource management and governance activities across the region. Workshop participants and interview respondents described the Weto Platform as an opportunity to bridge management gaps, to increase extension services, and to increase communication between rural communities and state institutions, such as Ghana's Wildlife Division, which administers protected areas and wildlife exploitation in the country as a whole, and the District Assembly. The District Assembly represents the lowest level of state government with resource management authority and was described as a key actor in the effective implementation of CBNRM.

Under the platform's encouragement, 8 communities have prepared land-use plans and 12 local bylaws were passed that aim to protect ecologically sensitive areas. Currently, there are 10 participating civil society organizations (CSOs) and nongovernmental organizations (NGOs) in the platform. One member organization is facilitating the process for the establishment of a new CREMA in the region, which will subsequently be called the Weto CREMA (Mock 2014). However, despite this encouraging progress, participants also identified several challenges that could potentially limit the impact of the platform. The main challenge identified was financial difficulties resulting in the lack of funds to cover operational expenses. Platform constituents suggested that until sustainable funding mechanisms are created, the Weto Platform will stagnate and will have difficulty reaching its stated goals. At the time of this research, contributing members no longer saw a clear advantage in joining, in paying dues, and contributing time and effort toward the platform.

\section{Zukpiri CREMA}

In Zukpiri, interview respondents described how years of unsustainable land-use practices had degraded arable lands and protected forests. Unsustainable practices included extensive slash and burn agriculture, uncontrolled bush burning, indiscriminate hunting, and the felling of trees for fuel. Such practices had resulted in declining crop yields and lower hunting returns for rural households. Many communities in the area also lacked a potable water supply, resulting in increased incidence of water borne diseases, such as guinea worm, typhoid fever, and bilharzia (Zintang Healers Association 2009). Access to healthcare facilities were described as limited and the widespread use of traditional medicine was seen as a viable option for community health care. Because of these continuing issues with land degradation and overexploitation of natural resources, the supply of traditional medicinal plants was threatened.

To address the disappearance of culturally important plants used in traditional healing practices, the Zintang Healers Association (ZHA) was founded as a community-based organization (CBO) in 2005. Its main objectives were to strengthen governance and community support around the use of traditional medicines. In the same year, the ZHA initiated the Zukpiri Integrated Wildlife Project to increase awareness around general land and resource degradation. This increased awareness led the ZHA and the local chiefs to partner with the UNDP SGP and the wildlife division to start the planning process for the creation of the Zukpiri CREMA.

Overall, the goals of the Zukpiri CREMA are to secure the production of natural resources through sound conservation practices and regulations, as well as to contribute to poverty reduction by offering opportunities to diversify livelihoods. Table 2 provides a list of the top five most important objectives of the CREMA, as perceived by survey respondents, i.e., individuals in the constituent communities. Respondents were presented a list of $20+$ possible objectives and asked to select the top five most important (in order) from that list. Table 2 only shows the objectives with the highest number of top rankings. These objectives represent a mix of general objectives, such as increased conservation awareness, and objectives specifically related to the particular issues the community was facing, such as the supply of traditional medicines. Many of the top-ranked objectives were related to a broad set of resources necessary for livelihoods in the area, such as more rain, grass, and bush-meat, as well as reduced fire.

Table 2. Results from a survey question asking respondents to select the five most important outcomes they were seeking from the community resource management area (CREMA). Findings strongly reflect the goals as described by key actors in the process, suggesting widespread community understanding of the CREMA.

\begin{tabular}{lccccc}
\hline \hline & \multicolumn{5}{c}{ Relative Importance of Outcome } \\
\cline { 2 - 6 } CREMA Goal & 1 st & 2nd & 3rd & 4 th & 5 th \\
\hline increased conservation awareness & 38 & 8 & 12 & 12 & 12 \\
more and better quality traditional & 36 & 38 & 15 & 11 & 11 \\
medicine & & & & & \\
more and better quality grass & 30 & 15 & 5 & 7 & 9 \\
more rain & 25 & 32 & 25 & 26 & 27 \\
increased employment & 17 & 14 & 20 & 26 & 29
\end{tabular}

Establishing the CREMA involved a number of steps, which included both governance and management interventions. First, CREMA boundaries were defined by mapping the borders of participating communities, communally held land, and what 
would become the core conservation zone within the new protected area. New governance structures were also created, including the formation of a community resource management committee (CRMC) at each individual community level, the creation of a coordinating CREMA executive committee (CEC), the development of a CREMA constitution, and the publication of new supporting CREMA bylaws that were approved by the Nadowli District Assembly. Bylaws are intended to affirm the existence of the CREMA within the district assembly, provide increased legitimacy to the CREMA's constitution, and prescribe rights of access for CREMA constituents.

Respondents described how the process of developing the CREMA was complemented by capacity-building activities led by various actors. For example, the ZHA facilitated technical training for constituent community members in sustainable agroforestry practices and land management. From 2002 to 2008, the Northern Savanna Biodiversity Conservation Project was implemented by the Ministry of Lands and Natural Resources to replant medicinal plants and to rehabilitate degraded areas. Within this project, various types of economic trees and crops were introduced, including mangoes (Mangifera indica), cashew (Anacardium occidentale), teak (Tectona grandis), moringa (Moringa oleifera), mahogany (Khaya spp.), sugar cane (Saccharum officiarum), banana (Musa spp.), and plantain (Musa paradisiaca). The Forest Services Division of the Forestry Commission implemented a similar training program focused on nursery establishment and management techniques, tree propagation, and transplanting methods, as well as the harvesting, drying, storing, and packaging of medicinal plants. In other livelihood support projects, the UNDP SGP and the Ministry of Food and Agriculture trained over 200 farmers in soil fertility technologies and the Nadowli District Assembly facilitated a program, financially supported by Care International, to help local farmers engage in dry season farming. Finally, the ZHA arranged for the Ghana National Fire Service to provide training for selected community members in fire prevention and control measures. As a result, a wide firebreak was constructed around the core area of the CREMA to prevent frequent bushfires from destroying the area. Various sections of the fire break were assigned to specific constituent communities to clear periodically. Fire prevention was successful for more than a decade until 2014 when failure on the part of some of the communities to clear their area resulted in the burning of a portion of the core conservation area (Zintang Mohammed 2017, personal observation).

The creation of the Zukpiri CREMA was not without challenges. For example, all farming and hunting were prohibited inside the demarcated core zone and some farmers had to be relocated outside this area. Affected individuals were given alternative places to farm, but many claimed they were given smaller, inferior pieces of land. The situation created tensions and heightened mistrust between CREMA executives, displaced farmers, and community groups. As a result, some people did not follow CREMA regulations and continued to farm and hunt within this core zone. To address the situation, chiefs and tindaanas (land priests) performed traditional rituals to caution community members of dire consequences for breaking and ignoring CREMA regulations. Respondents described how these interventions reduced tensions surrounding CREMA implementation and allowed for a higher degree of compliance.

\section{DISCUSSION}

The Zukpiri and the Akwapim-Togo Mountain Range case studies provide examples in which rural populations were trapped in persistent cycles of resource dependence, overexploitation, and unsustainable practices due to a range of social-ecological pressures. The structures, conditions, and processes leading to and maintaining these traps include changing land-tenure regimes, persistent tension between formal and customary management institutions, demographic change, as well as a lack of access to extension services, and noncompliance and weak enforcement capacity.

Both the Zukpiri CREMA and the Weto Platform attempted to reverse these social-ecological traps through intensive interventions that included, but were not limited to, modifying governance arrangements. Both cases highlighted attempts to develop new governance structures to promote collaboration between actors, including efforts to improve the linkages between existing customary institutions, local level agencies, and higher levels of government, as well as through the development of new organizational actors and drawing on the support of external, nongovernmental actors. For example, in Zukpiri, bylaws were created by the Nadowli District Assembly to link, reinforce, and nest the CREMA within the state government system. The formation of a new organizational actor, the Zintang Healers Association, provided a critical new organizational focal point to address persistent social-ecological issues and served as an important first step in CREMA establishment, which had considerable local support. The creation of the CREMA, along with its constitution, CRMC, and CEC allowed for collective discussions, the setting of shared priorities, and the crystallization of those conversations into new governance arrangements. The creation of the Weto Platform provides a similar example of a new structure that links various civil society groups, customary authorities, and state officials into a single institution, thus helping to improve communication between actors and to streamline landscape-level planning and development activities.

On the other hand, neither intervention was able to directly tackle the underlying issue of customary land and resource tenure, a clear driver creating and sustaining social-ecological traps in Ghana. Land and resource tenure emerged as central issues in both cases. Across Ghana, land tenure ambiguity has produced a grey area, in which noncompliance with environmental policy is frequent and the race to exploit land and resources is persistent. Our findings are consistent with other research conducted in Ghana on the implications of secured land and resource tenure for natural resource management (Boni 2006, Braimah et al. 2009), and McCarthy's (2004) research on Indonesian forests in which, given an ambiguous governance environment, forest users adopted short time horizons and raced to exploit natural resource. Because most land in Ghana remains under the trusteeship of a customary authority, many farmers do not have the right to formally register land. At the same time, the increasing commoditization and commercialization of land is putting immense pressure on customary land institutions to adequately deal with issues of land administration (Kuusaana and Gerber 2015). For example, across the Akwapim-Togo Mountains, farmers dwell in negative feedback loops of low inputs and low yields because they cannot access capital for technological improvements and do not have the collateral to obtain credit, which secure land tenure could provide. This has influenced 
decisions to (not) pursue reforestation and afforestation programming. On the other hand, in Zukpiri, relocated farmers continued to farm in the core zone, clearly ignoring CREMA policies, until the authority of customary systems were exerted.

The process of implementing both the Zukpiri CREMA and the Weto Platform were challenged in finding meaningful ways for customary and formal government actors to collaborate (Dawda and Dapilah 2013). The lack of recognition of customary management systems underpins many Ghanaian resource issues, serving to reduce collaboration between management efforts and incentives to enforce existing policy (Nyendu 2012). Despite significant efforts to reorganize institutions in Ghana, the state retains primary control over economically valuable resources, ultimately limiting access and power distribution to lower level actors. For example, although customary institutions maintain high levels of social legitimacy across the country, they do not have the legal right to harvest or financially benefit from naturally occurring trees on the landscape (GG-MLNR). This is illustrated in both cases through the inability to control fire on the landscape. Although the 1983 Bushfire Law makes a provision for the organization of volunteer fire squads in each community, it fails to empower customary authorities to play a role in enforcement and fails to equip fire squads with the necessary tools to fight fire (Kosoe et al. 2015). Constraints to fire policy implementation, in other words, reflect not only inadequate funding, logistics, and management capacity, but also a lack of integration between district assemblies and customary authorities (Kasanga and Kotey 2001, GG-MWRWH 2011, GG-MLNR 2012). More generally, these findings echo Ostrom's (1999) observations that when customary authorities are not formally recognized by larger state regimes, it is difficult for resource users and local-level institutions to enforce stated rules.

These results highlight how social-ecological traps can be maintained by a weak capacity to implement and enforce environmental policy and management plans. An additional likely reason for weak state capacity lies in insufficient fiscal decentralization, echoing work elsewhere that illustrates the failures of decentralization policies to actually transfer significant financial power, or capacity, back to local-level governments (Shackleton et al. 2002, Ribot and Peluso 2003, Clement 2010). Although the Ghanaian Constitution prescribes fiscal decentralization, local governments do not have the mandate to design their own budgets (Nyendu 2012). A lack of operating funds within local-level offices leave state officials unable to enforce regulations and unable to provide the extension services needed for communities to adapt to changing social-ecological contexts. For example, both cases describe situations in which there is an inability to control illegal logging and a general inaccessibility of state extension officers. Additionally, district assemblies are underfunded, understaffed, and without the resources needed to effectively manage resources and resource users (IUCN 2010, Damnyag et al. 2013, Kosoe et al. 2015). Moreover, the processes used to establish both the Zukpiri CREMA and the Weto Platform were supported by high levels of donor aid (Baruah et al. 2016). Internationally funded NGOs and intergovernmental organizations, like the GEF and the UNDP SGP, remain key players in facilitating CBNRM, running the risk CBNRM may not continue without such external support (Shackleton et al. 2002, Lockwood et al. 2010, Death 2013).
It is important to note that, in addition to attempting to adapt governance arrangements, in both cases the interventions placed significant attention on training and building local capacity to enable behavior change. Training objectives targeted community needs on very specific levels, such as in the production of medicinal plants, and on more general levels through the generation of alternative income sources and livelihood development. Training was delivered and facilitated by a variety of actors, including CBOs, groups within the formal state system, and external organizations. Thus, although some organizations may not have been directly involved in decision making related to the Weto Platform or the Zukpiri CREMA (though some were), their involvement nonetheless played a role in delivering social and ecological outcomes. In these cases, the involvement of nonlocal actors, such as loggers and industrial agriculturalists, has served to exacerbate social-ecological traps, and the involvement of other actors has been central in efforts to break them. Historically, the focus of CBNRM and development interventions has been on increasing local participation in management regimes (Ribot 2002). However, a growing body of research, including that presented here, shows that there is a clear need to refocus efforts to increase the capacity of local-level agencies, community members, and customary institutions to directly implement and carry-out interventions.

In considering the results, it is important to note that this study does not address whether these interventions have directly "broken" persistent traps, nor does it provide data on social or environmental outcomes, beyond the creation of new governance approaches and training programs. Given persistent conditions of poverty and the presence of external processes such as climate change and demographic shifts, the success of the Zukpiri CREMA and the Weto Platform is not guaranteed. However, the cases do illustrate that understanding the nature of socialecological traps, the need for capacity building, and the nuanced interactions between customary and state institutions can help target external interventions. Monitoring the success of such interventions, and the CREMA program more generally, is an important area for future research.

\section{CONCLUSION}

The case studies presented characterize the processes leading to and sustaining social-ecological traps in Ghana. Respondents in both case studies described persistent cycles of resource dependence and unsustainable practices, which were exacerbated by external processes including illegal logging, intensive agricultural development, and population growth. Moreover, Ghana presents unique governance challenges to effectively breaking traps, including a lack of administrative capacities to implement state policies, ongoing tensions between customary and state institutions, ambiguity regarding management responsibility and resource tenure, and a clear gap between stated resource management rules and the current socioeconomic and cultural context that necessitates everyday practice. The interventions described include targeted governance reform that sought to improve the linkages between existing institutions and a variety of new and nonlocal actors, complemented by investments in capacity building and training. Critically, training needs were closely tailored to locally variable objectives and capacity gaps (Garnett et al. 2007). This and other research suggest that CBNRM and the CREMA program have the 
potential to reframe and clarify governance and management responsibilities in Ghana and change the processes of entrapment (Braimah et al. 2009, Robinson and Sasu 2013, Agyare et al. 2015). However, the cases presented also highlight clear challenges to CBNRM and suggest that ultimately, reversing social-ecological traps cannot rely on single interventions or limited governance change. A deeper rethinking is required in how conservation and development policy is instituted to reorganize power relations across scales. Neither state management nor customary institutions acting alone are sufficient to reverse social-ecological traps.

Responses to this article can be read online at: http://www.ecologyandsociety.org/issues/responses. php/9992

\begin{abstract}
Acknowledgments:
We thank all who participated in the research for both case studies, all of whom generously shared their time and perspectives with us. Funding for fieldwork in the Akwapim-Togo Mountains was awarded by the Fox International Graduate Student Fellowship at Yale University. Additionally, the support from University of Ghana's Institute for Environmental and Sanitation Studies, especially the advice and oversight from Dr. Christopher Gordon, was instrumental to executing this case study. Funding for research on the Zukpiri Crema was conducted as part of a larger research program entitled "Protected Areas and Poverty Reduction: A Canada-Africa Research and Learning Alliance (PAPR)." Funding for PAPR comes from Social Sciences and Humanities Research Council of Canada and the International Development Research Centre under the International Community-University Research Alliance Program.
\end{abstract}

\section{LITERATURE CITED}

Adger, W. N., K. Brown, and E. L. Tompkins. 2005. The political economy of cross-scale networks in resource co-management. Ecology and Society 10(2):9. http://dx.doi.org/10.5751/ES-01465-100209

Agrawal, A., and C. C. Gibson. 1999. Enchantment and disenchantment: the role of community in natural resource conservation. World Development 27:629-649. http://dx.doi. org/10.1016/S0305-750X(98)00161-2

Agyare, A. K. 2013. Polycentric governance and social-ecological performance of community resource management areas in Ghana. Dissertation. University of Victoria, Victoria, British Columbia, Canada. [online] URL: http://dspace.library.uvic.ca/bitstream/ handle/1828/4930/Agyare Andrew PhD 2013.pdf?

sequence $=1 \&$ is Allowed $=\mathrm{y}$

Agyare, A. K., G. Murray, P. Dearden, and R. Rollins. 2015. Understanding inter-community performance assessments in community-based resource management at Avu Lagoon, Ghana. Environment, Development and Sustainability 17(6):1493-1508. http://dx.doi.org/10.1007/s10668-014-9617-7

Aryeetey, E., and C. Udry. 2010. Creating property rights: land banks in Ghana. American Economic Review 100(2):130-134. http://dx.doi.org/10.1257/aer.100.2.130
Asare, R. A., A. Kyei, and J. J. Mason. 2013. The community resource management area mechanism: a strategy to manage African forest resources for REDD+. Philosophical Transactions of the Royal Society B 368:2012-0311. http://dx.doi.org/10.1098/ rstb.2012.0311

Baruah, M., S. Bobtoya, P. Mbile, and G. Walters. 2016. Governance of restoration and institutions: working with Ghana's community resource management areas. World Development Perspectives 3:38-41. http://dx.doi.org/10.1016/j. wdp.2016.11.008

Batterbury, S. P. J., and J. L. Fernando. 2006. Rescaling governance and the impacts of political and environmental decentralization: an introduction. World Development 34 (11):1851-1863. http://dx.doi.org/10.1016/j.worlddev.2005.11.019

Berkes, F. 2007a. Community-based conservation in a globalized world. Proceedings of the National Academy of Sciences 104 (39):15188-15193. http://dx.doi.org/10.1073/pnas.0702098104

Berkes, F. 2007b. Commons in a multi-level world. International Journal of the Commons 2(1):1-6. http://dx.doi.org/10.18352/ ijc. 80

Boni, S. 2006. Ghanaian farmers' lukewarm reforestation: environmental degradation, the timber option and ambiguous legislation. Pages 1-12 in Colloque international "Les frontières de la question foncière - At the frontier of land issues." Institut de Recherche pour le Développement, Marseille, France. [online] URL: https://www.mpl.ird.fr/colloque foncier/Communications/ PDF/Boni.pdf

Boonstra, W. J., E. Björkvik, L. J. Haider, and V. Masterson. 2016. Human responses to social-ecological traps. Sustainability Science 11:877-889. http://dx.doi.org/10.1007/s11625-016-0397$\underline{\mathrm{x}}$

Boonstra, W. J., and F. W. de Boer. 2014. The historical dynamics of social-ecological traps. Ambio 43:260-274. http://dx.doi. org/10.1007/s13280-013-0419-1

Braimah, I., E. P. Tudzi, and T. Y. Baah-Ennumh. 2009. Land tenure as a challenge to the sustainability of the Amokwao community resource management area in Ghana. Journal of Sustainable Development in Africa 11(1):128-148.

Cinner, J. E. 2011. Social-ecological traps in reef fisheries. Global Environmental Change 21(3):835-839. http://dx.doi.org/10.1016/ j.gloenvcha.2011.04.012

Cinner, J. E, C, Huchery, M. A. MacNeil, N. A. J. Graham, T. R. McClanahan, J. Maina, E. Maire, J. N. Kittinger, C. C. Hicks, C. Mora, E. H. Allison, S. D’Agata, A. Hoey, D. A. Feary, L. Crowder, I. D. Williams, M. Kulbicki, L. Vigliola, L. Wantiez, G. Edgar, R. D. Stuart-Smith, S. A. Sandin, A. L. Green, M. J. Hardt, M. Beger, A. Friedlander, S. J. Campbell, K. E. Holmes, S. K. Wilson, E. Brokovich, A. J. Brooks, J. J. Cruz-Motta, D. J. Booth, P. Chabanet, C. Gough, M. Tupper, S. C. A. Ferse, U. R. Sumaila, and D. Mouillot. 2016. Bright spots among the world's coral reefs. Nature 535:416-419. http://dx.doi.org/10.1038/nature18607

Clement, F. 2010. Analysing decentralised natural resource governance: proposition for a "politicised" institutional analysis and development framework. Policy Sciences 43(2):129-156. http://dx.doi.org/10.1007/s11077-009-9100-8 
Damnyag, L., O. Saastamoinen, D. Blay, F. K. Dwomoh, L. C. N. Anglaaere, and A. Pappinen. 2013. Sustaining protected areas: identifying and controlling deforestation and forest degradation drivers in the Ankasa Conservation Area, Ghana. Biological Conservation 165:86-94. http://dx.doi.org/10.1016/j.biocon.2013.05.024

Dawda, T. D., and F. Dapilah. 2013. Challenges of the collaboration between formal local government actors and the chieftancy institution in Ghana: lessons from the Sissala East District of the Upper West Region of Ghana. International Journal of Humanities and Social Science 3(12):238-246. [online] URL:http://www.ijhssnet.com/journals/Vol_3_No_12_Special_Issue June 2013/27.pdf

Death, C. 2013. Environmental mainstreaming and postsovereign governance in Tanzania. Journal of Eastern African Studies 7(1):1-20. http://dx.doi.org/10.1080/17531055.2012.729777

Egyir, I. S., K. Ofori, G. Antwi, and Y. Ntiamoa-Baidu. 2015. Adaptive capacity and coping strategies in the face of climate change: a comparative study of communities around two protected areas in the coastal savanna and transitional zones of Ghana. Journal of Sustainable Development 8(1):1-15. http://dx. doi.org/10.5539/jsd.v8n1p1

Garnett, S. T., J. Sayer, and J. Du Toit. 2007. Improving the effectiveness of interventions to balance conservation and development: a conceptual framework. Ecology And Society 12 (1):2. http://dx.doi.org/10.5751/ES-01963-120102

Government of Ghana, Ministry of Lands and Natural Resources (GG-MLNR). 2016. A framework for tree tenure and benefit sharing scheme in Ghana. Ministry of Lands and Natural Resources, Accra, Ghana. [online] URL: https://www.fcghana. org/userfiles/files/NREG/Draft \%20Final\%20Report $30 \quad 05 \quad 16 \%$ 20.pdf

Government of Ghana, Ministry of Lands and Natural Resources (GG-MLNR). 2012. Ghana forest and wildlife policy. Ministry of Lands and Natural Resources, Accra, Ghana. [online] URL: https://www.documents.clientearth.org/wp-content/uploads/ library/2012-01-01-ghana-forest-and-wildlife-policy-2012-ext-en. pdf

Government of Ghana, Ministry of Water Resources, Works and Housing (GG-MWRWH). 2011. Riparian buffer zone policy for managing freshwater bodies in Ghana. Ministry of Water Resources, Works and Housing, Accra, Ghana. [online] URL: http://www.wrc-gh.org/dmsdocument/47

Government of Ghana, Wildlife Division of Ghana (GG-WDG). 2004. A briefing document on collaborative resource management in Ghana. Government of Ghana, Accra, Ghana. [online] URL: http://www.fcghana.org/assets/file/Publications/Wildlife\%20Issues/ collab resource mgt briefing.pdf

Hulme, D., and M. Murphree. 1999. Communities, wildlife and the 'new conservation' in Africa. Journal of International Development 11(2):277-285. http://dx.doi.org/10.1002/(SICI) 1099-1328(199903/04)11:2<277::AID-JID582>3.0.CO;2-T

International Union for Conservation of Nature (IUCN). 2010. Parks and reserves of Ghana: management effectiveness assessment of protected areas. IUCN, Gland, Switzerland. [online] URL: https://portals.iucn.org/library/sites/library/files/documents/2010-073. pdf
Kasanga, K., and N. A. Kotey. 2001. Land management in Ghana: building on tradition and modernity. International Institute for Environment and Development, London, UK. [online] URL: http://www.eldis.org/vfile/upload/1/document/0708/DOC5021.pdf

Kludze, A. K. P. 2000. Chieftaincy in Ghana. First edition. Austin and Winfield, Oxford, UK.

Kosoe, E. A., P. O.-W. Adjei, and W. Oduro. 2015. The forest fire problem of degrading Tain II Forest Reserve in Ghana: rethinking community participation in fire management and sustainable forestry. Ghana Journal of Geography 7(2):79-112. [online] URL: https://www.ajol.info/index.php/gjg/article/view/129219/118777

Kuusaana, E. D., and N. Gerber. 2015. Institutional synergies in customary land markets - selected case studies of large-scale land acquisitions (LSLAs) in Ghana. Land 4(3):842-868. http://dx.doi. org/10.3390/land4030842

Lawson, E. T., C. Gordon, and W. Schluchter. 2012. The dynamics of poverty-environment linkages in the coastal zone of Ghana. Ocean and Coastal Management 67:30-38. http://dx.doi. org/10.1016/j.ocecoaman.2012.05.023

Leach, M., R. Mearns, and I. Scoones. 1999. Environmental entitlements: dynamics and institutions in community based natural resource management. World Development 21(2):225-247. http://dx.doi.org/10.1016/S0305-750X(98)00141-7

Lemos, M. C., and A. Agrawal. 2006. Environmental governance. Annual Revue of Environment and Resources 31(1):297-325. http:// dx.doi.org/10.1146/annurev.energy.31.042605.135621

Levine, A. 2016. The development and unraveling of marine resource co-management in the Pemba Channel, Zanzibar: institutions, governance, and the politics of scale. Regional Environmental Change 16(5):1279-1291. http://dx.doi.org/10.1007/ s10113-015-0856-4

Lockwood, M., J. Davidson, A. Curtis, E. Stratford, and R. Griffith. 2010. Governance principles for natural resource management. Society and Natural Resources 23(10):986-1001. http://dx.doi.org/10.1080/08941920802178214

Masozera, M. K., J. R. R. Alavalapati, S. K. Jacobson, and R. K. Shrestha. 2006. Assessing the suitability of community-based management for the Nyungwe Forest Reserve, Rwanda. Forest Policy and Economics 8(2):206-216. http://dx.doi.org/10.1016/j. forpol.2004.08.001

McCarthy, J. F. 2004. Changing to gray: decentralization and the emergence of volatile socio-legal configurations in Central Kalimantan, Indonesia. World Development 32(7)1199-1223. http://dx.doi.org/10.1016/j.worlddev.2004.02.002

Mcgregor, A., S. Weaver, E. Challies, P. Howson, R. Astuti, and B. Haalboom. 2014. Practical critique: bridging the gap between critical and practice-oriented REDD+ research communities. Asia Pacific Viewpoint 55(3):277-291. http://dx.doi.org/10.1111/ apv.12064

Miller, D. C., A. Agrawal, and J. T. Roberts. 2013. Biodiversity, governance, and the allocation of international aid for conservation. Conservation Letters 6:12-20. http://dx.doi. org/10.1111/j.1755-263X.2012.00270.X 
Mock, G. 2014. Communities in action for landscape resilience and sustainability: the COMDEKS programme. United Nations Development Programme, New York, New York, USA. [online] URL: https://comdeksproject.files.wordpress.com/2014/10/communitiesin-action-comdeks-web-v2.pdf

Naughton-Treves, L., M. Buck Holland, and K. Brandon. 2005. The role of protected areas in conserving biodiversity and sustainable livelihoods. Annual Review of Environment and Resources 30:219-252. http://dx.doi.org/10.1146/annurev. energy.30.050504.164507

Nyendu, M. 2012. Democratic decentralization in Ghana: the need for a policy review. Journal of Asian and African Studies 47 (2):221-235. http://dx.doi.org/10.1177/0021909611422324

Ostrom, E., J. Burger, C. B. Field, R. B. Norgaard, and D. Policansky. 1999. Revisiting the commons: local lessons, global challenges. Science 284(5412):278-282. http://dx.doi.org/10.1126/ science. 284.5412 .278

Ribot, J. C. 2002. Democratic decentralization of natural resources: institutionalizing popular participation. World Resources Institute, Washington, D.C., USA. [online] URL: http://pdf.wri.org/ ddnr full revised.pdf http://dx.doi.org/10.1057/9781403981288 6

Ribot, J. C., and N. L. Peluso. 2003. A theory of access. Rural Sociology 68(2):153-181. http://dx.doi.org/10.1111/j.1549-0831.2003. $\underline{\mathrm{tb} 00133 . \mathrm{x}}$

Robinson, L. W., and K. A. Sasu. 2013. The role of values in a community-based conservation initiative in Northern-Ghana. Environmental Values 22(5):647-664. http://dx.doi. org/10.3197/096327113X13745164553914

Roe, D., F. Nelson, and C. Sandbrook. 2009. Community management of natural resources in Africa: impacts, experiences and future directions. International Institute for Environment and Development, London, U.K. [online] URL: http://pubs.iied.org/ pdfs/17503IIED.pdf

Shackleton, S., B. Campbell, E. Wollenberg, and D. Edmunds. 2002. Devolution and community-based natural resource management: creating space for local people to participate and benefit? ODI Natural Resource Perspectives 76:1-6. [online] URL: https://www.odi.org/sites/odi.org.uk/files/odi-assets/publicationsopinion-files/2811.pdf

Young, O. 2006. Vertical interplay among scale dependent resource regimes. Ecology and Society 11(1):27. http://dx.doi. org/10.5751/ES-01519-110127

Zintang Healers Association. 2009. Report on the achievement and activities of Zintang Healers Association on the Zukpiri Integrated Wildlife Project. Zintang Healers Association, Wa, Ghana. 